\title{
Harmonia axyridis: What will stop the invader?
}

\author{
António Onofre Soares · Isabel Borges · Paulo A. V. Borges · \\ Geneviève Labrie · Éric Lucas
}

Received: 24 September 2007/ Accepted: 2 November 2007/Published online: 27 November 2007

(C) International Organization for Biological Control (IOBC) 2007

\begin{abstract}
In recent years Harmonia axyridis (Pallas, 1773) (Coleoptera: Coccinellidae) has become a very popular insect among biological control practitioners and scientists, not only for its potential to be an efficient biological control agent but also because it is considered invasive. Individuals of this species were deliberately introduced into several countries for biological control of different arthropods pests. However the predator itself became an invasive species, affecting the dynamics and composition of several guilds through direct or indirect interactions with established species, including intraguild predation. In this paper we discuss the reasons why the species has a high invasiveness and what are the limits to invasion by this species. It is not clear if the invasiveness of the beetle is linked to its biological, ecological and behavioural abilities, or to other factors such as invasibility and interactions between the invaders, the noninvaders, and the habitat, which may in part explain the reasons of its success and help us to answer the question "what will stop the invader?" We also discuss the reason for the absence of the predator in the Azores islands. Despite the intentional introduction of $H$. axyridis in the Azores and the high number of individuals released, there are no records of this species in the wild, despite recent extensive sampling effort. In this paper we discuss the reasons for the apparent failure or the delay in establishment of the predator. One factor which may hamper the establishment of $H$. axyridis in some of the Azores islands is the absence of winter
\end{abstract}

\footnotetext{
A. O. Soares $(\bowtie) \cdot$ I. Borges

Departmento de Biologia, CIRN, Universidade dos Açores, Rua da Mãe de Deus, 13-A, 9501-801

Ponta Delgada, Azores, Portugal

e-mail: onofre@uac.pt

P. A. V. Borges

Departmento de Ciências Agrárias, CITAA, Universidade dos Açores, 9700-851 Angra do Heroísmo, Azores, Portugal

G. Labrie · É. Lucas

Département des Sciences Biologiques, Université du Québec à Montréal, C.P. 8888 Succursale Centre-ville, Montreal, QC, Canada H3C 3P8
} 
environmental conditions, mainly the temperature which is seldom lower than $12^{\circ} \mathrm{C}$, essential for the induction of diapause. The lack of success in the establishment could be also related to functional diversity saturation, that is species saturation and competitive exclusion of $H$. axyridis by other previously established species may be operating.

Keywords Harmonia axyridis · Invader · Invasion · Invasibility · Invasiveness · Europe $\cdot$ Azores

\section{Biological invasions by insect species, why?}

The concept of biological invasion is, generally, used to refer to the arrival or introduction, establishment, geographical expansion and integration of a species into a region where it has never been before (Williamson 1996; Shigesada and Kawasaki 1997). Biological invasion includes several processes, such as the importation, introduction and establishment but also the integration of the novel species into the new habitat, after ecological and evolutionary interaction with local species (Vermeij 1996). Invasion is considered a natural phenomenon over evolutionary time scales, with biotic interchange between large regions occurring frequently (Vermeij 2005). However, recent humanassisted invasions are considered to be one of the most important mechanisms of global environmental change and are considered the second leading threat for worldwide biodiversity, after habitat destruction (Vitousek et al. 1996, 1997; Pimentel et al. 2000; Simberloff 2004).

Most invasions occur due to commerce, agriculture and travelling (Williamson 1996; Liebhold et al. 2006). In the USA, the majority of plants and vertebrates were intentionally introduced while the introductions of invertebrate animals were mostly accidental (Pimentel et al. 2000; see also Liebhold et al. 2006). Among the 50,000 species introduced in the United States of America, over 4,500 were arthropods, including insect species, aquatic invertebrates and crabs and 1,300 of them have successfully established (Mooney and Drake 1989; Pimentel et al. 2000, 2005). The economic cost of biodiversity losses, damages and control for the USA was estimated to be $\$ 120$ billion per year (Pimentel et al. 2005). The figure may continue to rise in the future (Levine and D'Antonio 2003). The introduction and release of exotic biological control agents generally used for classical and inundative biological control programmes are also of concern for invasion biologists and conservationists. The mass production and release of generalist organisms that are flexible (and so easily adapt to their new habitat), increase the probability of impact on non-target organisms. This may lead to displacement and extinction of indigenous species (Simberloff 1996; Simberloff and Stiling 1996; Williamson 1996; Evans 2004).

Predictions and ecological theory about successful introductions of insect species are still imprecise. However, inconclusive evidence suggests that non-indigenous species are limited to those sites under anthropogenic influence, located mainly in marginal places, and the rate of expansion of those species to native sites has still to be tested (Borges et al. 2006a). Simberloff (1989) referred to the importance of habitat modification for the success and failure of insect invasion. He stated that conclusions drawn about pristine habitats may not apply to modified habitats. For this reason the author presented several examples and counter-examples on the importance of opportunity for colonization, suitable habitat, biotic resistance hypothesis and biological traits favouring successful introductions on different modified habitats. The success of an invasion may include deterministic elements 
(for details see Crawley 1989) but also stochastic elements relating to good luck and good timing (Crawley 1989). However, the importance of chance and timing may differ from case to case and from process to process (Crawley 1989). Does this fact explain why Harmonia axyridis Pallas (Coleoptera: Coccinellidae) took so long to become an invader in some regions? The forces contributing to the outcome cannot be specified and measured, and the final result can be viewed as a random draw from a specified distribution (Simberloff 1989). Moreover, crucial empirical data is lacking concerning records of failed invasions (Holt et al. 2005), which is an impediment to our knowledge of the factors contributing to the lack of species invasions.

Marco et al. (2002) presented and defined a set of factors directly involved in conceptual framework to formulate the biological invasion problem into a modelling context. These authors referred to two main factors which may hamper and promote the invasion process: the biological traits that enable the species to invade a new habitat (invasiveness), and the new habitat characteristics that determine its susceptibility to the establishment and spread of the invader (invasibility). A third important aspect linking invasiveness and invasibility is the interaction among the invaders, the noninvaders, and the habitat. There are a small number of studies specifically addressing the reasons why $H$. axyridis has succeeded or failed as an invader in different regions. However taking the conceptual framework of Marco et al. (2002) and the large number of studies and reviews on the biology (Koch 2003), ecology, and behaviour of the predator we can discuss some of the reasons for the successes and failures of the introduction of $H$. axyridis in non-native regions and begin to consider what will stop the invader.

\section{Harmonia axyridis: where and when?}

Harmonia axyridis is native to many regions of Asia, such as Formosa, Manchuria, China, Korea, Japan, southern Siberia, Ryukyu Islands and the Bonin Islands (Iablokoff-Khnzorian 1982). Several introductions of the species were made in North America between 1916 and 1985, namely in California in 1916, 1964, and 1965 (Gordon 1985), in Nova Scotia (Canada), Connecticut, Delaware, Georgia, Maine, Maryland, Mississippi, Ohio, Pennsylvania, and Washington (USA) from 1978 to 1982 (Gordon 1985). Specimens were also released in Connecticut in 1985 during a study of the potential of $H$. axyridis to control Matsucoccus resinosae Bean and Godwin (Homoptera: Margarodidae) (McClure 1987). This species preys on more than 30 different aphid species and so was considered as a suitable candidate for efficient biological control against many pests including: aphids (see Lucas et al. 2007a; Tedders and Schaefer 1994; Hodek and Honĕk 1996), Tetranychidae (Lucas et al. 1997, 2002), Psyllidae (Fye 1981; Michaud 2001, 2002, 2004), Coccoidea (McClure 1986), Chrysomelidae (Snyder and Clevenger 2004), Curculionidae (Kalaskar and Evans 2001; Stuart et al. 2002) and Lepidoptera (Koch et al. 2003, 2005; Musser and Shelton 2003a). Its large body size, high voracity and predation efficiency (Schanderl et al. 1985; Osawa 2000; Soares et al. 2001; Labrie et al. 2006) as well as its good colonization efficiency (Osawa 2000; With et al. 2002) were considered good characteristics to provide successful biological control of many pests. This coccinellid seems to be an effective biological control agent; upon review of 27 studies of $\mathrm{H}$. axyridis as a biocontrol agent (Lucas et al. 2007a), 17 studies showed effective biological control of 16 different pest species by this coccinellid. However, in the 24 studies on the impact of $H$. axyridis on competitors, 15 demonstrated a negative impact by exploitative competition or intraguild predation (Lucas et al. 2007a). 


\section{Harmonia axyridis: a super invader?}

Harmonia axyridis is expected to become ubiquitous in most temperate countries. Why such a great invasive success?

Harmonia axyridis formula; champion of the invaders?

The Champion hypothesis postulates that $H$. axyridis has exceptional capacities allowing it to be successful in any new environment. This means that the biological attributes of the beetle are particularly well designed to permit invasion into new areas. Several morphological, physiological and behavioural traits of the beetle support this hypothesis.

Morphological traits such as the relatively large body size of the beetle compared to other aphidophagous species (Hodek 1973; Michaud 2002), and the presence of spines on the back of third and fourth larval instars could provide a protection from intraguild or higher-order predation (IGP) (Lucas unpublished data). The ovoid shape of adults as well as bright colour may also confer a protection from predators and competitors (De Clercq et al. 2003). In addition, H. axyridis is a highly polymorphic species (Soares et al. 2001) and this could also help the species to be an efficient invader. Many modifications, such as elytral patterns, body shape and body size may be adaptive through imparting increased tolerance to adverse conditions (Dobzhansky 1933; Soares et al. 2003a). The relative frequency of phenotypes seems to be related to geographical and seasonal factors (Tan 1946, 1949; Komai 1956; Iablokoff-Khnzorian 1982; Osawa and Nishida 1992), suggesting that some phenotypes may be favorably selected in different parts of the ecosystem or at different times. Thus the genetic polymorphism in $H$. axyridis seems to be the strategy adopted for facing different habitats at different times. Phenotypical macro-geographic variation in Asian populations of $H$. axyridis was related mainly to climatic factors, because pale and melanic phenotypes have different physiological responses to climatic conditions, particularity to relative humidity and temperature (Komai 1956). Environmental temperature and elytra colour in ladybird beetles may affect body temperature (Brakefield and Willmer 1985; Stewart and Dixon 1989; De Jong et al. 1996) and, thus biological activities. The relative frequency of elytral pattern phenotypes also varies with the host plants (micro-geographic variation) suggesting that they could be correlated with the different aphid populations found on these plants (Komai and Hosino 1951). The key point may be that the suitability of different prey species differs for different phenotypes. Recent laboratory study suggests that different phenotypes may thrive on different prey species in the wild (Soares et al. 2005). All these results, driven from field observations and laboratory experiments, suggest that habitats with more complex structures (presenting diverse abiotic field conditions and food sources) increase the possibility of successful establishment by different phenotypes of $H$. axyridis. Nevertheless, correlation between genetic polymorphism, adaptability and invasiveness may not necessarily be very close in some regions. For instance in North America, despite the dominance of the f. succinea phenotype across the region, $H$. axyridis was able to succeed as an invader all over that geographic area.

Physiological characteristics, such as development, fecundity and low susceptibility to pathogens could allow its successful invasion in a new environment. A key factor in the invasion process is juvenile growth, as safe conditions in these vulnerable stages can ensure high population growth in the new environment (Marco et al. 2002). A shorter development time of younger larval instars of $H$. axyridis compared to the indigenous 
Coleomegilla maculata lengi Timberlake (Coleoptera: Coccinellidae) in Canada was observed in North America (Labrie et al. 2006). Size, strength of the integument and distastefulness of the pupae make this stage less vulnerable to predation (Félix and Soares 2004; Labrie unpublished data). According to several studies, fecundity of $\mathrm{H}$. axyridis is higher than other species, with between 703 and 3,800 eggs laid by a single female in laboratory studies (Iablokoff-Khnozorian 1982; Stathas et al. 2001; Mignault et al. 2006). For example, fecundity of $H$. axyridis (2,008 eggs per female) reared on soybean aphids Aphis glycines Matsumura (Homoptera: Aphididae) was significantly higher than the invasive Propylea quatuordecimpunctata L. (Coleoptera: Coccinellidae) (593 eggs per female) or the indigenous C. maculata (390) in Québec, Canada (Mignault et al. 2006). Physiological ability to withstand unfavourable environmental conditions is another key factor. No winter survival was observed in USA (McClure 1987) and Canada (Labrie et al. 2007) when the coccinellid was held outside during winter season. However, survival was observed inside households (Labrie et al. 2007), where this species forms swarms of thousands in the autumn (Kidd and Nalepa 1995; LaMana and Miller 1996; Nalepa et al. 1996; Hagley 1999; Huelsman et al. 2001; Kovach 2004). Households provided a cold-free space for this species (and possibly an enemy-free space), which has allowed geographical extension to the northern part of North America and contributed the invasive success of $H$. axyridis. Indeed the success of $H$. axyridis may be partly linked to the enemy release hypothesis (the potential invader is successful because of the inefficacy of natural enemies in the new area) (Gratton and Welter 1999; Keane and Crawley 2002; Stastny et al. 2005; Halpern and Underwood 2006). An invasive species in a new region is hypothesised to experience a decrease in regulation by natural enemies, resulting in an increase in distribution and abundance (Keane and Crawley 2002). Laboratory and field data report low levels of successful parasitism of $H$. axyridis adults by Dinocampus coccinellae Schrank (Hymenoptera: Braconidae) in North America (Hoogendoorn and Heimpel 2002; Firlej et al. 2005) or in Italy (Burgio et al. 2007). Even if $H$. axyridis is sympatric with D. coccinellae in Asia (Maeta 1969), the degree of coevolution between H. axyridis and D. coccinellae remains unknown because the parasitoid native area is unclear (America or Europe) (Balduf 1926). Other entomopathogens, such as Beauveria bassiana (Balsamo) Vuillemin (Ascomycota: Hypocreales) (Cottrell and Shapiro-Ilan 2003; Roy et al. 2007), or nematodes (Shapiro-Ilan and Cottrell 2005) did not affect survival of $H$. axyridis in North America.

Behavioural traits of $H$. axyridis have certainly contributed to its invasive success. A superior ability to acquire resources can strongly affect the invaders survival and fecundity, and may confer a large competitive advantage in the invaded range (Petren and Case 1996). An increase in foraging efficiency could allow the invasive species to cope with competition. Harmonia axyridis larvae and adults have been shown to have a higher predation and foraging efficiency than indigenous species (Yasuda and Ohnuma 1999; Yasuda et al. 2001; Lanzoni et al. 2004; Labrie et al. 2006). Higher conversion efficiency of prey into biomass was also observed for this species (Labrie et al. 2006), which could increase its exploitative competition ability and population density.

In the same way, the response (or lack thereof) of a non-indigenous species to novel predators and competitors in the new community will likely affect the overall invasion success and potential for impact by the invader. It has been demonstrated that $H$. axyridis is more aggressive than other invasive and indigenous species in many laboratory experiments (Hironori and Katsuhiro 1997; Cottrell and Yeargen 1998; Yasuda and Ohnuma 1999; Snyder et al. 2004; Yasuda et al. 2001; Cottrell 2004; Soares and Serpa 2007; Pell et al. 2007; Ware and Majerus 2007). The incidence of IGP, in laboratory studies, was $65 \%$ 
for the interactions between all stages of $H$. axyridis (intraguild predator) and the indigenous C. maculata (intraguild prey), and $75 \%$ for $H$. axyridis and the invasive $P$. quatuordecimpunctata (Labrie et al. unpublished data). This indicates that $H$. axyridis is highly aggressive and has the potential to compete with other species.

The $H$. axyridis formula; one species among the others?

These impressive traits may not be the only ones contributing to the success of $H$. axyridis. Would the coccinellid have such ubiquity on 2007 in absence of human intervention? Obviously no. This species has been extensively and repeatedly released in several areas (see Table 1) and its success may be strongly linked to human activity. Can we postulate that other aphidophagous coccinellids may have a similar response to new environment? From the literature, we can compare several aphidophagous coccinellids with $H$. axyridis. For example, despite shorter developmental time of second and fourth larval instars of $H$. axyridis compared to $C$. maculata, the overall developmental time was similar between the two species (Labrie et al. 2006). Furthermore, other studies demonstrated a slower developmental time of $H$. axyridis in comparison to other species (Adalia bipunctata L., Hippodamia variegata Goeze, Lanzoni et al. 2004; P. quatuordecimpunctata, Mignault et al. 2006; Olla v-nigrum Mulsant, Michaud and Olsen 2004).

While, as previously stated, $H$. axyridis showed high fecundity, other studies demonstrated similar or lower fecundity than indigenous species (Bazzochi et al. 2004; Lanzoni et al. 2004; Michaud and Olsen 2004; Soares et al. 2004). For example, in Italy, the mean fecundity of $H$. axyridis (783.8 eggs per female) was only slightly higher than an indigenous species, A. bipunctata (720.2 eggs per female) (Bazzochi et al. 2004). Lower fecundity of $H$. axyridis (560.5 eggs per female) compared to $H$. variegata (841.7 eggs per female) was observed in laboratory by Lanzoni et al. (2004). Soares et al. (2004) demonstrated an even lower fecundity than these experiments suggest, with a mean fecundity of 314 eggs per female for the aulica phenotype of $H$. axyridis in laboratory. Experiments of Michaud and Olsen (2004) on psyllids demonstrated similar fecundity of $H$. axyridis (242.8 eggs per female) to $O$. v-nigrum (224.5 eggs per female). Fecundity of this invasive species seems thus similar to some other aphidophagous species.

Harmonia axyridis is a highly efficient intraguild predator (Hironori and Katsuhiro 1997; Cottrell and Yeargen 1998; Yasuda and Ohnuma 1999; Snyder et al. 2004; Yasuda et al. 2001; Cottrell 2004; Soares and Serpa 2007; Pell et al. 2007; Ware and Majerus 2007). However, eggs and first and second instar larvae are not well protected from other competitors. Recent laboratory investigations demonstrated that $61-85 \%$ of $\mathrm{H}$. axyridis eggs were consumed by $C$. maculata and $P$. quatuordecimpunctata (Labrie et al. unpublished data). In these experiments, first and second larval instars were also very vulnerable to predation, with $66 \%$ and $31 \%$ being consumed by C. maculata and P. quatuordecimpunctata, respectively. This species is also attacked by hemipteran species, such as Podisus maculiventris (Say) (Hemiptera: Pentatomidae) in the laboratory (De Clercq et al. 2003) or repeatedly in the field (Labrie personal observation).

Wise et al. (2001) reported 11 new Coccinellidae species in Manitoba (Canada) including of which $H$. axyridis and $C$. maculata lengi. In Québec (Canada), four aphidophagous coccinellids are dominant in agricultural crops, three invasive species $(H$. axyridis, Coccinella septempunctata L. and P. quatuordecimpunctata) and one indigenous ( $C$. maculata) and coexist widely (Lucas et al. 2007b). Could the majority of aphidophagous species be potential invasive species? To our knowledge, no aphidophagous predators exploit a single 
Table 1 Continental areas and islands where the introduction or invasion by the multicoloured Asian ladybeetle has occurred

\begin{tabular}{llll}
\hline $\begin{array}{l}\text { Countries and } \\
\text { Islands }\end{array}$ & Status & Year & References \\
\hline
\end{tabular}

Continental areas

Asia

\begin{tabular}{|c|c|c|c|}
\hline China & Indigenous & & Iablokoff-Khnzorian (1982) \\
\hline Korea & Indigenous & & Iablokoff-Khnzorian (1982) \\
\hline Manchuria & Indigenous & & Iablokoff-Khnzorian (1982) \\
\hline Siberia & Indigenous & & Iablokoff-Khnzorian (1982) \\
\hline Ukraine & Invasion & 1964 & $\begin{array}{l}\text { Brown et al. (2007); } \\
\quad \text { Katsoyannos et al. (1997) }\end{array}$ \\
\hline
\end{tabular}

Europe

\begin{tabular}{|c|c|c|c|}
\hline Austria & Invasion & 2006 & $\begin{array}{l}\text { Brown et al. (2007); } \\
\text { Rabitsch and Schuh (2006) }\end{array}$ \\
\hline Belarus & Introduction & 1968 & Sidlyarevich and Voronin (1973) \\
\hline Belgium & Introduction & 1997 & Adriaens et al. (2003) \\
\hline Czech Republic & Introduction & 2003,2006 & $\begin{array}{l}\text { Brown et al. (2007); } \\
\text { Nedved and Kovar } \\
\text { (unpublished data) }\end{array}$ \\
\hline Denmark & Invasion & 2006 & Brown et al. (2007) \\
\hline France & Introduction & 1982 & Schanderl et al. (1985) \\
\hline Germany & Introduction & 1997 & Iperti and Bertrand (2001) \\
\hline Greece & Introduction & 1994 & Katosyannos et al. (1997) \\
\hline Holland & Introduction & 1996 & Iperti and Bertrand (2001) \\
\hline Italy & Introduction & 1990’s & Iperti and Bertrand (2001) \\
\hline Liechtenstein & Invasion & 2007 & $\begin{array}{l}\text { Brown et al. (2007); } \\
\text { Loomans (unpublished data) }\end{array}$ \\
\hline Luxembourg & Invasion & 2004 & $\begin{array}{l}\text { Brown et al. (2007); Schneider and } \\
\text { Loomans (2006) }\end{array}$ \\
\hline Norway & Invasion & 2006 & $\begin{array}{l}\text { Brown et al. (2007); } \\
\quad \text { Staverloekk et al. (2007) }\end{array}$ \\
\hline Portugal & Introduction & 1984 & Garcia (1986) \\
\hline Spain & Introduction & 1995 & $\begin{array}{l}\text { Brown et al. (2007); } \\
\text { SIFA (2004) }\end{array}$ \\
\hline Sweden & Invasion & 2007 & $\begin{array}{l}\text { Brown et al. (2007); } \\
\text { Hägg (unpublished data) }\end{array}$ \\
\hline Switzerland & Introduction & 1996 & $\begin{array}{l}\text { Brown et al. (2007); } \\
\text { Andermatt (1996) }\end{array}$ \\
\hline \multicolumn{4}{|l|}{ nerica } \\
\hline Argentina & Invasion & 2001 & Saini (2004) \\
\hline Brazil & Invasion & 2002 & De Almeida and da Silva (2002) \\
\hline Canada & Invasion & 1994 & Coderre et al. (1995) \\
\hline USA & Introduction & $1916-1980$ & Gordon (1985) \\
\hline South Africa & & 2007 & Stals and Prinsloo (2007) \\
\hline
\end{tabular}


Table 1 continued

\begin{tabular}{llll}
\hline $\begin{array}{l}\text { Countries and } \\
\text { Islands }\end{array}$ & Status & Year & References \\
\hline $\begin{array}{l}\text { Islands } \\
\text { Azores }\end{array}$ & Introduction & $1988-1995$ & Garcia (1986) \\
& & Schanderl et al. (1991) \\
& & & Schanderl and Almeida (1992) \\
Bonin & Indigenous & & Iablokoff-Khnzorian (1982) \\
Canary & Introduction & 2003 & Carrillo (2006) \\
Formosa & Indigenous & & Iablokoff-Khnzorian (1982) \\
Great Britain & & & \\
England & Invasion & 2004 & Majerus et al. (2006) \\
Wales & Invasion & 2006 & Brown et al. (2007) \\
Hawaii & Introduction & 1916 & Schanderl (1987) \\
Japan & Indigenous & & Iablokoff-Khnzorian (1982) \\
Møn & Invasion & 2007 & Brown et al. (2007) \\
Ryukyu & Invasion & 2006 & Jan Pedersen \\
(personal communication)
\end{tabular}

The "year" on the table means the date of the introduction or the first record, after invasion

aphid species, but instead feed on an array of different prey species (euryphagous), on different host plants and in different environments (eurytopic) (Iablokoff-Khnozorian 1982; Hodek and Honěk 1996). They are also good competitors (Elliott et al. 1996; Ellis et al. 1999; Alyokhin and Sewell 2004; Evans 2004) which could allow all these species to invade new environments. Moreover, one may invoke the neutral theory of biodiversity (Bell 2005; Hubbell 2001, 2005, 2006) which suggest that all species are identical and compete equally, once all species can develop on a site. Composition of the community will thus be determined by stochastic dispersion of individuals.

Concluding, we would say that the $H$. axyridis formula is linked to an ability to invade and establish in new environments through growth, development, reproduction and survival under diverse abiotic and biotic conditions. We would also add that several other aphidophagous coccinellids are already invasive or have the potential to invade, and it is not so clear that $H$. axyridis is more adapted or "superior" than these other species in the invasive process. Finally, the $H$. axyridis phenomenon appears to be because of the bio-ecological attributes of this beetle and the exceptional mobilization of the scientific community around this conspicuous and "apparent" beetle.

\section{Where will it end?}

Harmonia axyridis has demonstrated its ability to establish in new different areas. Can we predict how this situation will evolve? Which new areas will follow? What would stop or limit $H$. axyridis? Considering Southern countries, $H$. axyridis is present in Korea. But it has not been cited in equatorial or in arid zones. The beetle enters into aestivation when the temperature is too hot, this phase of dormancy is representative of an acclimation to 
climatic exigencies, but could hamper the optimal functioning of the beetle if such conditions are common.

Considering Northern countries, H. axyridis is found in south Siberia (Russia) and also in Canada (Iablokoff-Khnzorian 1982; Coderre et al. 1995) indicating that this beetle has the capacity to deal with cold climates. In United States, McClure (1987) showed however that survival was greatly reduced during winter and Labrie et al. (2007) demonstrated that $0 \%$ of the individuals survived outside during the Canadian winter. However survival was assured by the behaviour of overwintering inside human houses. This behaviour allowed survival of about $25 \%$. According to these studies, we may conclude that the northern limitation is more a matter of availability of suitable overwintering location, such as human houses rather than climatic conditions.

Considering the favourable temperate conditions of continental European countries, colonization of European areas is predicted to continue, since no climatic, biophysical traits seem to be detrimental to the beetle. However, considering islands, the isolation could delay colonization despite Great Britain was recently colonized (Brown et al. 2007).

\section{Azores, the first failure of $H$. axyridis?}

Until recently, the importation and introduction of exotic species as biocontrol agents was one of the strategies to control exotic pests on crops. Research on how to increase environmental resistance to invasion has not received sufficient attention (Ehler 1998). Theory says that oceanic islands are especially vulnerable to biological invasions due to: (i) many empty available niches leading to a non-saturation of communities, i.e., there are plenty resources available for new species to enter the communities; (ii) taxonomic disharmony, i.e., many families or genera are lacking in island biotas which facilitates the invasion by species with different evolutionary characteristics; (iii) small population size-as species accumulate within an island, competition between indigenous species could led to lower average population sizes, which facilitates the invasion by a new highly competitive exotic species; (iv) facilitation processes, that is, species are nurseries for other species and consequently invasion rate should rise in islands with low functional diversity (Williamson 1981; Gillespie and Roderick 2002; Whittaker and Fernández-Palacios 2007). As a consequence of (i) and (ii) usually poor island communities have low resistance to invasion by non-native species, although this seems to vary with the scale of study (Borges et al. 2006a). In fact, native insect communities that achieved ecological equilibrium diversity in high altitude unfragmented and undisturbed native forests are more resistant to invasion by exotic species (Borges et al. 2006a). For instance, most exotic arthropod species in the Azores are more abundant in human-made disturbed habitats than in native forest (Borges et al. in press a). One other example of the impact of human-caused introduction on the structure and function of ecosystems was the invasion of the Christmas Island by the yellow crazy ant Anoplolepis gracilipes (Fr. Smith) (Hymenoptera: Formicidae). The effects of this species on the habitat of that island were evident on the dynamics of the forest floor and species richness of the canopy. Moreover, long-term effects on forest structure and composition were evident in the reduced seedling recruitment, reduced species richness of seedlings, slow litter breakdown and low density of litter invertebrates (O'Dowd et al. 2003). The mutualistic interaction between the invader and scale-insects led to outbreaks of these Homoptera and may explain the decrease of the proportion of growing shoots and dieback in the canopies of large trees (O'Dowd et al. 2003). In the Azores low altitude canopy communities are dominated by introduced ants that replaced 
the dominant indigenous spider fauna still occurring at pristine high altitude forests (see Borges et al. in press a, unpublished data). As shown by Borges et al. (2006a) invasions of alien arthropod species are an actual and future environmental threat in the Azores, creating a pattern of biotic homogenization that is of great contemporary concern. In the case of the Azorean archipelago, almost $60 \%$ of the beetle fauna is non-native (Borges et al. 2005), and the coccinellids community is also mainly composed of exotic species. In fact, at least 14 out of 23 species were considered exotic (Borges et al. 2005).

Since the 1980's, several individuals of $H$. axyridis were introduced into five islands of the Azores (Sta. Maria, Pico, S. Jorge, Faial and Terceira) to control citrus and corn aphid pests (Garcia 1986; Schanderl et al. 1991; Schanderl and Almeida 1992). In 1991, 1,500 H. axyridis adults were released in a corn field of Pico Island to study the dispersion and the distribution on plants (Schanderl et al. 1991). From 1988 to 1990, between May and June, 152,996 third larval stages of the coccinellid were released into several citrus orchards on the small island of Sta. Maria $\left(97 \mathrm{~km}^{2}\right.$ ) (Schanderl and Almeida 1992). Every single year, and after each release, short-term surveys were performed in Sta. Maria to record the presence and follow the dispersion of the exotic species. During these surveys, it was possible to verify that the species was able to successfully disperse and some individuals were found far away from the release sites; on the wall of the houses or feeding on citrus, apple trees and bean plants (Schanderl and Almeida 1992). Those results suggested the possibility of a successful introduction.

However, recent publications on the terrestrial fauna and flora biodiversity from the Azores did not report the presence of $H$. axyridis in the archipelago (Borges et al. 2005). An investigation of the occurrence patterns of several species of Coccinellidae in the well studied island of Terceira (Borges et al. in press a) shows that nine species were sampled in eight different habitats, none of them were $H$. axyridis. Remarkably, eight out of nine species were sampled mainly in orchards ( $89 \%$ of the species and $95 \%$ of the specimens), habitats where H. axyridis may be found (Michaud 2002). Thus, the Azorean coccinellid community is composed mainly of recently introduced species well adapted to humanmade habitats. These results may suggest that in fact $H$. axyridis did not become established in the Azores. How can we explain this apparent failure of the establishment of this invasive predator in the Azores? Firstly we must not exclude the hypothesis predicting that $H$. axyridis is already established in the Azores and that small populations were not detected because of a lack of long term-surveys specifically addressed to check for its establishment and dispersal over the islands, mainly in Pico and Santa Maria. It is known that approximately $90 \%$ of all introduced species fail to establish viable populations in new environments (Williamson 1996). Could the invasion of $H$. axyridis be limited by the absence of suitable habitats? Probably not since the beetle is eurytopic, exploiting agricultural systems, forests, marshes, or urban areas. Could the invasion be limited by the absence of suitable resources? Probably not. H. axyridis is euryphagous, exploiting mites (Lucas et al. 1997, 2002), psyllids (Michaud 2001, 2002, 2004) and other insect species. Furthermore, in Canada for example, at the end of the autumn, when all indigenous species have reached their overwintering sites, numerous individuals of the beetle are found in agricultural fields. At this time, there are virtually no preys for the beetles in the field. We noticed that larvae achieved their preimaginal development by cannibalising other individuals. Independently of the results reported before, a question remains unanswered; will invasion and establishment of $H$. axyridis into the Azores be inevitable?

In North America, $H$. axyridis was released without success in many climatically and ecologically different regions over 70 years, but then it became established. In Europe, some releases also failed (e.g. Ukraine, Greece, Italy, and France) before eventually 
invading Europe. In the case of the Azores, have the particular biotypes released been unsuitable for establishment? Lombaert et al. (2007) state that populations maintained in controlled laboratory conditions should become specialised on a narrow range of environments and hence show lower phenotypic plasticity. These authors found some evidence of differences between invasive and commercialised populations for traits ecologically relevant for the invasive potential of populations. The individuals released in the Azores came from a mass production of INRA-Antibes, which may have limited the introduction to a single biotype of the predator. However, the results of Lombaert et al. (2007) only poorly support the idea of increased phenotypic plasticity being a cornerstone of invasive success of at least some European populations. Thus using a limited strain of the predator may not explain the success or failure in the invasion process.

The Azores presents a temperate oceanic climate, i.e., strongly influenced by the proximity of the ocean and by its topography, which results in high levels of relative atmospheric humidity. The type of climate also restricts temperature fluctuations throughout the year (Azevedo 2005). The milder temperatures occurring over the spring and the summer seasons in the Azores are very close to the thermal optimum for foraging and breeding activities of $H$. axyridis (Schanderl et al. 1985) and thus, the Azorean temperatures seem not to be a limiting factor of its invasiveness. Indeed Poutsma et al. (2007), using the CLIMEX programme (v2), predicted that establishment and spread seem likely in many temperate regions across the world including a large part of temperate and Mediterranean Europe, North and South America, Australia and New Zealand. During the winter, however, the average minimum temperature in the Azores (Azevedo 2005) is very close to the minimum thermal requirement (Schanderl et al. 1985) which could hamper diapause of the adults, and may result in keeping them active during this season.

Harmonia axyridis is a species which is found, preferentially, in arboreal habitats (Iablokoff-Khnzorian 1982). In Belgium, this predator has became dominant on this type of habitat (Adriaens et al. 2007). The vegetation of the Azores archipelago is, however, dominated by the grasslands used for cattle feeding and a wide variety of plant communities, including coastal vegetation, wetland vegetation (lake shore and seashore communities and a variety of bogs), several types of paddies, and different types of native shrub and forest (Borges et al. in press a, b). In general, the vegetation of those plant communities is composed by therophyte, hemycryptophyte and camaephytes non-indigenous life form of plants, found in walking trails, roads, crop margins, pastures, field crops, native shrub and costal areas (Silva and Smith 2006), which may be less suitable for the predator. Arboreal habitats are also present in the Azores but, in general, they are small, fragmented and composed by different combinations of the natives plants Myrica faya Ait, Laurus azorica (Seub.) Franco, Persea indica (L.) Spreng. and the non-indigenous Pittosporum undulatum Vent., Acacia melanoxylon R. Br., Cryptomeria japonica Regius (Silva and Smith 2006). However, aphid species are mostly found on the less suitable annual non-native plants habitats than on the preferential arboreal habitats (Borges et al. 2006b). These factors may limit the establishment of H. axyridis in the Azores. On the other hand, alternative and suitable habitats such as field crops and orchards, vineyards, hedgerows and gardens on urban environments may be searched by the invader (Iablokoff-Khnzorian 1982; Adriaens et al. 2007). For instance, corn fields are important for feeding and reproductive activity of $H$. axyridis in many invaded areas (Musser and Shelton 2003b; Nault and Kennedy 2003; Lundgren et al. 2004; Musser et al. 2004; Park and Obrycki 2004; Firlej et al. 2005). Corn fields are common on the Azores and, thus, have the potential to contribute to the establishment of $H$. axyridis.

One factor which may hamper the establishment of $H$. axyridis in the Azores is the absence of winter environmental conditions for the overwintering strategy. In order to face 
food scarcity and unfavourable weather, most temperate coccinellid do have an obligatory diapause (Dixon 2000; Hodek and Honĕk 1996). Harmonia axyridis has a true and obligatory diapause (Sakurai et al. 1992), after a period of feeding and reproductive activity, somewhere from April to October (Ongagna et al. 1993; LaMana and Miller 1996; Katsoyannos et al. 1997; Bazzochi et al. 2004). Temperature, photoperiod and scarcity of food are key factors for the induction of the coccinellid diapause. Photoperiod may not be a limiting factor for diapause of $H$. axyridis because geographical position of the Azores $\left(37^{\circ}-40^{\circ} \mathrm{N}\right.$ latitude), is very similar to other regions where $H$. axyridis diapause. Would it be possible that $H$. axyridis requires large thermal fluctuations not present in these islands in order to have a satisfactory diapause? In Japan and south-eastern of France, H. axyridis interrupts its reproduction when temperature is low (below $12^{\circ} \mathrm{C}$ ) and the daylight short (Ongagna et al. 1993; Watanabe 2002). The optimum temperature for overwintering is between 0 and $-5^{\circ} \mathrm{C}$ (Watanabe 2002). Winter annual temperature occurring in the Azores may not allow a sufficiently long period for diapause by individuals. In the small mountain regions of the Azores, average minimum temperature usually falls below $12^{\circ} \mathrm{C}$ but for short time, i.e. $2-3$ months. A temperature of $0{ }^{\circ} \mathrm{C}$ is possible only on the Pico Mountain $(2,351 \mathrm{~m}$ ) of Pico Island (Azevedo 2005). In the habitats (crops and orchards) where $H$. axyridis could feed and reproduce, that is, on the lowlands of the islands, the temperature is seldom lower than $12^{\circ} \mathrm{C}$. This fact may hamper the induction of diapause. We cannot exclude the possibility of $H$. axyridis feeding during winter throught the presence of alternative food sources like pollen, conspicuous patches of aphids and coccids standing on plants throughout the year on the evergreen plants in the lowlands and even cannibalizing larvae. We may also hypothesise that there could be a possible progressive selection against a tendency for obligatory onset of diapause under the environmental condition of the Azores. Indeed some laboratory studies on the incidence of diapause of $C$. septempunctata over successive generations show a tendency for obligatory onset of diapause under long days conditions (Hodek and Honĕk 1996). This tendency was never demonstrated under laboratory conditions for $H$. axyridis.

One important dimension of the invasiveness is the presence of species occupying the same ecological niche. The invaders may be involved in intraguild predation events or competition, either through exploitative or interference competition. The presence of other aphidophagous coccinellids is very common on the islands as Scymnus, Nephus and Rhyzobius species (Soares et al. 2003b; Borges et al. 2005) with which H. axyridis may interact. These genera present small individuals, apparently having small competitive abilities. Recent results suggest that $H$. axyridis could endanger the populations of one of the large aphidophagous coccinellids of the islands; Coccinella undecimpunctata L. The study considered the magnitude, direction and symmetry of intraguild predation between the developmental stages of the $H$. axyridis and $C$. undecimpunctata and showed that $H$. axyridis was more often the predator than $C$. undecimpunctata and also that eggs were the most vulnerable developmental stage (Félix and Soares 2004). Moreover, laboratory experiments demonstrated that the presence of $H$. axyridis adults significantly affected the reproductive numerical response of $C$. undecimpunctata even though the resource was not in short supply. The results suggested that interference competition with heterospecifics may adversely affect the reproductive capacity of $C$. undecimpunctata (Soares and Serpa 2007).

Recent studies suggest that the invasion success of many species might depend more heavily on their ability to respond to natural selection than on broad physiological tolerance or plasticity (Lee 2002). One possibility for the lack of success in the establishment of H. axyridis in the Azores could be related to functional diversity saturation. As mentioned above, most of the coccinellid assemblages in the Azores occurs in orchards and other 
man-made ecosystems. This could imply species saturation and competitive exclusion of $H$. axyridis by other previously established species. However, this has to be proved through robust experiments and intensive field surveys in several islands of the archipelago (see Borges et al. 2006a, in press a).

It could also be that $H$. axyridis has a lag phase in its establishment. Maybe the establishment success and persistence of $H$. axyridis will be dependent on repeated introductions to avoid the genetic drift effect and increase the genetic diversity of the source population.

\section{Conclusion}

The environmental risks associated with the invasion of insects introduced for biological control, like $H$. axyridis, were seldom taken into account. The effectiveness of generalist predators in biological control may be diminished if increased availability of alternative prey causes individual predators to decrease their consumption of the target species. In fact, intraguild predation is common among generalist predators and is an important issue in food web theory. Therefore, increased attention has to be paid to the harmful effects of introduced biological control agents on non-target indigenous species.

Several studies have stressed the biological, ecological and behavioural characteristics that make $H$. axyridis a strong invader, among them, its aggressiveness (as an intraguild predator), polyphagy, fecundity and the fact that it is a less habitat and niche-specific coccinellid than native species. However, the " $H$. axyridis phenomena" may give a false impression of the real potential of the coccinellid to be an invader. This may result from the fact that $H$. axyridis is one of the coccinellid species most extensively studied by the scientific community; it has been released in more locations and more often than any other coccinellid species and by its overwintering behaviour inside human houses, is a great concern for citizens. For the reasons presented before, it is not clear if $H$. axyridis formula is enough to make it "superior" to the other coccinellid species for invasion.

In contrast to the invasiveness of $H$. axyridis, less attention has been paid to the invasibility issue. Invasibility may, in part, explain the reasons for the success (or failure) of establishment of $H$. axyridis and answering the question "what will stop the invader?" In the case of the Azores and despite the deliberated introduction, the occurrence of a temperate climate and crop, garden and arboreal habitats infested with suitable aphids for the predator, it may not be enough to the establishment of the species. Indeed other factors, such as the presence of the aphids on the less suitable annual non-native plants habitats than on the preferential arboreal habitats and the absence of winter annual temperature for the diapause, may explain the apparent failure on its establishment. The lack of success in the establishment of $H$. axyridis in the Azores could be related to functional diversity saturation, that is species saturation and competitive exclusion of $H$. axyridis by other previously established species may be operating. However there is an urgent need to determine accurately the underlying factors that have, so far, prevented the establishment of $H$. axyridis within the sensitive ecosystems of the Azores, focusing on standardized sampling of several habitats in islands subjected to historical releases of specimens (e.g., Sta. Maria, Pico, S. Jorge, Faial, and Terceira).

Acknowledgements The authors would like to thank Peter Brown for his helpful comments on Table 1 and for sending original references about geographical distribution of $H$. axyridis in Europe. Thanks are also due to Ivo Hodek and Luis Silva, for their helpful comments on the following topics, overwintering of ladybird beetles and vegetation cover on the Azores, respectively. 


\section{References}

Adriaens T, Branquart E, Maes D (2003) The multicolored Asian ladybird Harmonia axyridis Pallas (Coleoptera: Coccinellidae), a threat for native aphid predators in Belgium? Belg J Zool 133:195-196

Adriaens T, San Martin y Gomez G, Maes D (2007) Invasion history, habitat preferences and phenology of the invasive ladybird Harmonia axyridis in Belgium. BioControl (this issue). doi:10.1007/s10526-007-9137-6

Alyokhin A, Sewell G (2004) Changes in a lady beetle community following the establishment of three alien species. Biol Invasions 6:463-471

Andermatt M (1996) Marienkäferlarven als blattlaus-bekämpfungsmittel? Andermatt Biocontrol 3:10-11

Azevedo EB (2005) "Projecto CLIMAAT_Clima e Meteorologia dos Arquipélagos Atlânticos"—Interreg IIIB, MAC 2.3/A3-Açores, Madeira e Canárias. http://www.climaat.angra.uac.pt. Accessed 19 Sept 2007

Balduf WV (1926) The bionomics of Dinocampus coccinellae Schrank. Ann Entomol Soc Am 19:465-489

Bazzochi GG, Lanzoni G, Accinelli G, Burgio G (2004) Overwintering, phenology and fecundity of Harmonia axyridis in comparison with native coccinellid species in Italy. BioControl 49:245-260

Bell G (2005) The co-distribution of species in relation to the neutral theory of community ecology. Ecology 86:757-770

Borges I, Soares AO, Hemptinne J-L (2006b) Abundance and spatial distributions of aphids and scales select for different life histories in their ladybird beetle predators. J Appl Entomol 130:461-464

Borges PAV, Cunha R, Gabriel R, Martins AF, Silva L, Vieira V, Dinis F, Lourenço P, Pinto N (2005) Description of the terrestrial Azorean biodiversity. In: Borges PAV, Cunha R, Gabriel R, Martins AMF, Silva L, Vieira V (eds) A list of the terrestrial fauna (Mollusca and Arthropoda) and flora (Bryophyta, Pteridophyta and Spermatophyta) from the Azores. Direcção Regional de Ambiente and Universidade dos Açores, Horta, Angra do Heroísmo and Ponta Delgada

Borges PAV, Lobo JM, Azevedo EB, Gaspar C, Melo C, Nunes VL (2006a) Invasibility and species richness of island endemic arthropods: a general model of endemic vs. exotic species. J Biogeogr 33:169-187

Borges PAV, Ugland KI, Dinis FO, Gaspar C (in press a) Insect and spider rarity in an oceanic island (Terceira, Azores): true rare and pseudo-rare species. In: Fattorini S (ed) Insect ecology and conservation. Research Signpost

Borges PAV, Amorim IR, Cunha R, Gabriel R, Martins AF, Silva L, Costa A, Vieira V. (in press b) Azoresbiology. In: Gillespie R, Clagu D (eds) Encyclopedia of Islands. University of California Press, California

Brakefield PM, Willmer PG (1985) The basis of thermal-melanism in the ladybird Adalia bipunctata: differences in reflectance and thermal properties between the morphs. Heredity 54:9-14

Brown PMJ, Adriaens T, Bathon H, Cuppen J, Goldarazena A, Hägg T, Kenis M, Klausnitzer BEM, Kovar I, Loomans AJM, Majerus MEN, Nedved O, Pedersen J, Rabitsch W, Roy HE, Ternois V, Zakharov IA, Roy DB (2007) Harmonia axyridis in Europe: spread and distribution of a non-native coccinellid. BioControl (this issue). doi:10.1007/s10526-007-9132-y

Burgio G, Lanzoni A, Accinelli G, Maini S (2007) Estimation of mortality by entomophages on exotic Harmonia axyridis versus native Adalia bipunctata in semi-field conditions in northern Italy. BioControl (this issue). doi:10.1007/s10526-007-9133-x

Carrillo AM (2006) El sarantontón asiático Harmonia axyridis (Pallas, 1773) presente en Canárias (Coleoptera: Coccinellidae). Vieraea 34:71-72

Coderre D, Lucas E, Gagne I (1995) The occurrence of Harmonia axyridis (Pallas) (Coleoptera, Coccinellidae) in Canada. Can Entomol 127:609-611

Cottrell TE (2004) Suitability of exotic and native lady beetle eggs (Coleoptera: Coccinellidae) for development of lady beetle larvae. Biol Control 31:362-371

Cottrell TE, Shapiro-Ilan DI (2003) Susceptibility of a native and an exotic lady beetle (Coleoptera: Coccinellidae) to Beauveria bassiana. J Invertebr Pathol 84:137-144

Cottrell TE, Yeargan KV (1998) Intraguild predation between an introduced lady beetle Harmonia axyridis (Coleoptera: Coccinellidae), and a native lady beetle, Coleomegilla maculata (Coleoptera: Coccinellidae). J Kans Entomol Soc 71:159-163

Crawley JC (1989) Chance and timing in biological invasions. In: Drake JA, Mooney HA, di Castri F, Groves RH, Kruger FJ, Rejmánek M, Williamson M (eds) Biological invasion: a global perspective. Scope 37. Wiley, Chichester

De Almeida LM, da Silva VB (2002) Primeiro registro de Harmonia axyridis (Pallas) (Coleoptera, Coccinellidae): um coccinelideo originario da região Paleartica. Revta Bras Zool 19:941-944

De Clercq P, Peeters I, Vergauwe G, Thas O (2003) Interaction between Podisus maculiventris and Harmonia axyridis, two predators used in augmentative biological control in greenhouse crops. BioControl 48:39-55 
De Jong PW, Gussekloo SWS, Bakefield PM (1996) Differences in thermal balance, body temperature and activity between non-melanic and melanic two-spot ladybird beetles (Adalia bipunctata) under controlled conditions. J Exp Biol 199:2655-2666

Dixon AFG (2000) Insect predator-prey dynamics: ladybird beetles \& biological control. Cambridge University Press, Cambridge

Dobzhansky ThG (1933) Geographical variations in lady-beetles. Am Nat 709:97-126

Ehler LE (1998) Invasion biology and biological control. Biol Control 13:127-133

Elliott N, Kieckhefer R, Kauffman W (1996) Effects of an invading coccinellid on native coccinellids in an agricultural landscape. Oecologia 105:537-544

Ellis DR, Prokrym DR, Adams RG (1999) Exotic lady beetle survey in northeastern United States: Hippodamia variegata and Propylea quatuordecimpunctata (Coleoptera: Coccinellidae). Entomol News 110:73-84

Evans EW (2004) Habitat displacement of North American ladybirds by an introduced species. Ecology $85: 637-647$

Félix S, Soares AO (2004) Intraguild predation between the aphidophagous ladybird beetles Harmonia axyridis and Coccinella undecimpunctata (Coleoptera: Coccinellidae): the role of body weight. Eur J Entomol 101:237-242

Firlej A, Boivin G, Lucas É, Coderre D (2005) First report of Harmonia axyridis Pallas being attacked by Dinocampus coccinellae Schrank in Canada. Biol Invasions 7:553-556

Fye RE (1981) Rearing and release of coccinellids for potential control of pear Psylla. Agric Res Serv (Western Region) 20:1-9

Garcia V (1986) Approaches to integrated control of some citrus pests in the Azores and Algarve (Portugal). In: Cavalloro R, Di Martino E (eds) Integrated pest control in citrus groves. Proc. CEC Experts Meeting, Acireale

Gillespie RG, Roderick GK (2002) Arthropods on Islands: colonization, speciation, and conservation. Annu Rev Entomol 47:595-632

Gordon RD (1985) The Coccinellidae (Coleoptera) of America north of Mexico. J N Y Entomol Soc 93:1-912

Gratton C, Welter SC (1999) Does "enemy-free space" exist? Experimental host shifts of an herbivorous fly. Ecology 80:773-785

Hagley EAC (1999) Predatory insects in fruit orchards in Southern Ontario. Publication 208 Agriculture and Agri-Food Canada and Ontario Ministry of Agriculture, Food and Rural Affairs, $32 \mathrm{pp}$

Halpern SL, Underwood N (2006) Approaches for testing herbivore effects on plant population dynamics. J Appl Ecol 43:922-929

Hironori Y, Katsuhiro S (1997) Cannibalism and interspecific predation in two predatory ladybirds in relation to prey abundance in the field. Entomophaga 42:153-163

Hodek I (1973) Biology of Coccinellidae. Dr. W. Junk NV Publishers, The Hague, Prague

Hodek I, Honěk A (1996) Ecology of Coccinellidae. Kluwer Academic Publishers, Dordrecht, 464 pp

Holt RD, Brakefield M, Gomulkiewicz R (2005) Theories of niche conservation and evolution-could exotic species be potential pest? In: Sax DF, Stachowicz JJ, Gaines SD (eds) Species invasions-insights into ecology, evolution and biogeography. Sinauer Associates, Inc. Publishers, Massachusetts

Hoogendoorn M, Heimpel GE (2002) Indirect interactions between an introduced and a native ladybird beetle species mediated by a shared parasitoid. Biol Control 25:224-230

Hubbell SP (2001) The unified neutral theory of biodiversity and biogeography. Princeton monographs in population biology. Princeton University Press, Princeton

Hubbell SP (2005) Neutral theory in community ecology and the hypothesis of functional equivalence. Funct Ecol 19:166-172

Hubbell SP (2006) Neutral theory and the evolution of ecological equivalence. Ecology 87:1387-1398

Huelsman MF, Jasinski J, Young C, Kovach J (2001) The multicolored Asian lady beetle (Harmonia axyridis) as a nuisance pest in households throughout Ohio. http://ipm.osu.edu/lady/icup.htm. Accessed 5 Sept 2007

Iablokoff-Khnzorian SM (1982) Les Coccinelles; Coléoptères-Coccinellidae. Société Nouvelle des Editions Boubée, Paris, 568 pp

Iperti G, Bertrand E (2001) Hibernation of Harmonia axyridis (Coleoptera: Coccinellidae) in South-Eastern France. Acta Soc Zool Bohem 65:207-210

Kalaskar A, Evans EW (2001) Larval responses of aphidophagous lady beetles (Coleoptera: Coccinellidae) to weevil larvae versus aphid as prey. Ann Entomol Soc Am 94:76-81

Katsoyannos P, Kontodimas DC, Stathas GJ, Tsartsalis CT (1997) Establishment of Harmonia axyridis on citrus and some data on its phenology in Greece. Phytoparasitica 25:183-191

Keane RM, Crawley MJ (2002) Exotic plant invasions and the enemy release hypothesis. TREE 17:164-170

Kidd KA, Nalepa CA (1995) Distribution of Harmonia axyridis (Pallas) (Coleoptera: Coccinellidae) in North Carolina and Virginia. Proc Entomol Soc Wash 97:729-731 
Koch RL (2003) The multicoloured Asian lady beetle, Harmonia axyridis: a review of its biology, uses in biological control and non-target impacts. J Insect Sci 3:1-16

Koch RL, Hutchison WD, Venette RC, Heimpel GE (2003) Susceptibility of immature monarch butterfly, Danaus plexippus (Lepidoptera: Nymphalidae: Danainae), to predation by Harmonia axyridis (Coleoptera: Coccinellidae). Biol Control 28:265-270

Koch RL, Venette RC, Hutchison WD (2005) Influence of alternate prey on predation of monarch butterfly (Lepidoptera: Nymphalidae) larvae by the multicolored Asian lady beetle (Coleoptera: Coccinellidae). Environ Entomol 34:410-416

Komai T (1956) Genetics of ladybeetles. Adv Genet 8:155-189

Komai T, Hosino Y (1951) Contributions to the evolutionary genetics of the lady-beetle, Harmonia. II. Microgeographic variations. Genetics 36:382-390

Kovach J (2004) Impact of multicolored Asian lady beetles as a pest of fruit and people. Am Entomol 50:159-161

Labrie G, Coderre D, Lucas E (2007) Overwintering strategy of the multicolored Asian ladybeetle (Coleoptera: Coccinellidae): a cold-free space as a factor of invasive success. Ann Entomol Soc Am (in press)

Labrie G, Lucas E, Coderre D (2006) Can developmental and behavioral characteristics of the multicolored Asian lady beetle Harmonia axyridis explain its invasive success? Biol Invasions 8:743-754

LaMana ML, Miller JC (1996) Field observations on Harmonia axyridis Pallas (Coleoptera: Coccinellidae) in Oregon. Biol Control 6:232-237

Lanzoni A, Accinelli G, Bazzocchi GG, Burgio G (2004) Biological traits and life table of the exotic Harmonia axyridis compared with Hippodamia variegata and Adalia bipunctata (Col. Coccinellidae). J Appl Entomol 128:298-306

Lee CE (2002) Evolutionary genetics of invasive species. TREE 17:386-391

Liebhold AM, Work TT, Mccullough DG, Cavey JF (2006) Airline baggage as a pathway for alien insect species invading the United States. Am Entomol 52:48-54

Levine JM, D'Antonio CM (2003) Forecasting biological invasions with increasing international trade. Conserv Biol 17:322-326

Lombaert E, Malausa T, Devred R, Estoup A (2007) Phenotypic variation in invasive and biocontrol populations of the harlequin ladybird, Harmonia axyridis. BioControl (this issue). doi:10.1007/s10526-007-9131-z

Lucas E, Coderre D, Vincent C (1997) Voracity and feeding preferences of two aphidophagous coccinellids on Aphis citricola and Tetranychus urticae. Entomol Exp Appl 85:151-159

Lucas E, Gagné I, Coderre D (2002) Impact of the arrival of Harmonia axyridis on adults of Coccinella septempunctata and Coleomegilla maculata (Coleoptera: Coccinellidae). Eur J Entomol 99:457-463

Lucas E, Labrie G, Vincent C, Kovach J (2007a) The multicolored Asian ladybeetle, Harmonia axyridisbeneficial or nuisance organism? In: Vincent C, Goettel M, Lazarovitz G (eds) Biological control: a global perspective. CABI Publishing, UK

Lucas E, Vincent C, Labrie G, Chouinard G, Fournier F, Pelletier F, Bostanian NJ, Coderre D, Mignault M-P, Lafontaine P (2007b) The multicolored Asian ladybeetle Harmonia axyridis in Quebec agroecosystems ten year after its arrival. Eur J Entomol 104:737-743

Lundgren JG, Razzak AA, Wiedenmann RN (2004) Population responses and food consumption by predators Coleomegilla maculata and Harmonia axyridis (Coleoptera: Coccinellidae) during anthesis in an Illinois cornfield. Environ Entomol 33:958-963

Maeta Y (1969) Biological studies on the natural enemies of some Coccinellid beetles. I. On Perilitus coccinellae (Schrank). Kontyu 37:147-166

Majerus M, Strawson V, Roy H (2006) The potential impacts of the arrival of the harlequin ladybird, Harmonia axyridis (Pallas) (Coleoptera: Coccinellidae), in Britain. Ecol Entomol 31:207-215

Marco DA, Páez SA, Cannas SA (2002) Species invasiveness in biological invasions: a modelling approach. Biol Invasions 4:193-205

McClure MS (1986) Role of predators in regulation of endemic populations of Matsucoccus matsumurae (Kuwana) (Homoptera: Margarodidae) in Japan. Environ Entomol 15:976-983

McClure MS (1987) Potential of the Asian predator, Harmonia axyridis Pallas (Coleoptera: Coccinellidae), to control Matsucoccus resinosae Bean and Godwin (Homoptera: Margarodidae) in the United States. Environ Entomol 16:224-230

Michaud JP (2001) Numerical response of Olla v-nigrum (Coleoptera: Coccinellidae) to infestations of Asian citrus psyllid, (Hemiptera: Psyllidae) in Florida. Fla Entomol 84:608-612

Michaud JP (2002) Biological control of Asian citrus psyllid, Diaphorina citri (Hemiptera: Psyllidae) in Florida: a preliminary report. Entomol News 113:216-222

Michaud JP (2004) Natural mortality of Asian citrus psyllid (Homoptera: Psyllidae) in central Florida. Biol Control 29:260-269 
Michaud JP, Olsen LE (2004) Suitability of Asian citrus psyllid, Diaphorina citri, as prey for ladybeetles. BioControl 49:417-431

Mignault M-P, Roy M, Brodeur J (2006) Soybean aphid predators in Québec and the suitability of Aphis glycines as prey for three Coccinellidae. BioControl 51:89-106

Mooney HA, Drake JA (1989) Biological invasions: a SCOPE program overview. In: Drake JA, Mooney HA, di Castri F, Groves RH, Kruger FJ, Rejmánek M, Williamson M (eds) Biological invasion: a global perspective. Scope 37. Wiley, Chichester

Musser FR, Shelton AM (2003a) Predation of Ostrinia nubilalis (Lepidoptera: Crambidae) eggs in sweet corn by generalist predators and the impact of alternative foods. Environ Entomol 32:1131-1138

Musser FR, Shelton AM (2003b) Factors altering the temporal and within-plant distribution of coccinellids in corn and their impact on potential intraguild predation. Environ Entomol 32:575-583

Musser FR, Nyrop JP, Shelton AM (2004) Survey of predators and sampling method comparison in sweet corn. J Econ Entomol 97:136-144

Nalepa CA, Kidd KA, Ahlstrom KR (1996) Biology of Harmonia axyridis (Coleoptera, Coccinellidae) in winter aggregations. Ann Entomol Soc Am 89:681-685

Nault BA, Kennedy G (2003) Establishment of multicolored Asian lady beetle in Eastern North Carolina: seasonal abundance and crop exploitation within an agricultural landscape. BioControl 48:363-378

O'Dowd DJ, Green PT, Lake PS (2003) Invasional "meltdown" on an oceanic island. Ecol Lett 6:812-817

Ongagna P, Giuge L, Iperti G, Ferran A (1993) Cycle de développement d'Harmonia axyridis (Col. Coccinellidae) dans son aire d'introduction : le sud-est de la France. Entomophaga 38:125-128

Osawa N (2000) Population field studies on the aphidophagous ladybird beetle Harmonia axyridis (Coleoptera: Coccinellidae): resource tracking and population characteristics. Popul Ecol 42:115-127

Osawa N, Nishida T (1992) Seasonal variation in elytral colour polymorphism in Harmonia axyridis (the ladybird beetle): the role of non-random mating. Heredity 69:297-307

Park Y-L, Obrycki JJ (2004) Spatio-temporal distribution of corn leaf Aphids (Homoptera: Aphididae) and ladybeetles (Coleoptera: Coccinellidae) in Iowa cornfields. Biol Control 31:210-217

Pell JK, Baverstock J, Roy HE, Ware RL, Majerus MEN (2007) Intraguild predation involving Harmonia axyridis: a review of current knowledge and future perspectives. BioControl (this issue). doi: $10.1007 / \mathrm{s} 10526-007-9125-\mathrm{x}$

Petren K, Case TJ (1996) An experimental demonstration of exploitation competition in an ongoing invasion. Ecology 77:118-132

Pimentel D, Lach L, Zuniga R, Morrison D (2000) Environmental and economic cost of nonindigenous species in the United States. Bioscience 50:53-65

Pimentel D, Zuniga R, Morrison D (2005) Update on the environmental and economic costs associated with alien-invasive species in the United States. Ecol Econ 52:273-288

Poutsma J, Loomans AJM, Aukema B, Heijerman T (2007) Predicting the potential geographical distribution of the harlequin ladybird, Harmonia axyridis, using the CLIMEX model. BioControl (this issue). doi:10.1007/s10526-007-9140-y

Rabitsch W, Schuh R (2006) First record of the multicoloured Asian ladybird Harmonia axyridis (Pallas, 1773) in Austria. Beiträge Zur Entomofaunistik 7:161-164

Roy HE, Brown PMJ, Rothery P, Ware RL, Majerus MEN (2007) Interactions between the fungal pathogen Beauveria bassiana and three species of coccinellid: Harmonia axyridis, Cocinella septempunctata and Adalia bipunctata. BioControl (this issue). doi:10.1007/s10526-007-9122-0

Saini ED (2004) Presencia de Harmonia axyridis (Pallas) (Coleoptera: Coccinellidae) en la provincia de Buenos Aires. Aspectos Biologicos y Morfologicos Ria 33:151-160

Sakurai H, Kawai T, Takeda S (1992) Physiological changes related to diapause of the lady beetle, Harmonia axyridis (Coleoptera: Coccinellidae). Appl Entomol Zool 4:479-487

Schanderl H (1987) Détermination des conditions optimales d'élevage de la coccinelle Harmonia axyridis Pallas (Col., Coccinellidae), et possibilité d'une production continue à l'aide d'une proie de substitution, les œufs d'Ephestia kuehniella Zeller (Lep., Pyralidae). Dissertation, Université de Droit, d'Economie et des Sciences, d'Aix-Marseille III

Schanderl H, Almeida JM (1992) Introdução de Harmonia axyridis Pallas (Col., Coccinellidae) na ilha de S. Maria. Açoreana 7:401-406

Schanderl H, Ferran A, Larroque MM (1985) Les besoins trophiques et thermiques des larves de la coccinelle Harmonia axyridis Pallas. Agronomie 5:417-421

Schanderl H, Ferran A, Coderre D, Ventura A, Soares AO, Almeida JMP, Taveira J (1991) Capacidade de dispersão de Harmonia axyridis Pallas (Col., Coccinellidae) após uma largada inundativa para controlo de afídeos do Milho Rhopalosiphum padi L. e Sitobion avenae F. (Hom., Aphididae). Relatórios e Comunicações do Departamento de Biologia 20:59-64 
Schneider N, Loomans AJM (2006) Sur la présence au Luxembourg de la coccinelle arlequin Harmonia axyridis (Pallas, 1773) (Insecta, Coleoptera, Coccinellidae). Bulletin de la Société des Naturalistes Luxembourgeois 106:71-74

Shapiro-Ilan DI, Cottrell TE (2005) Susceptibility of lady beetles (Coleoptera: Coccinellidae) to entomopathogenic nematodes. J Invertebr Pathol 89:150-156

Shigesada N, Kawasaki K (1997) Biological invasions: theory and practice. Oxford University Press, Oxford Sidlyarevich VI, Voronin KE (1973) Trials on using Leis axyridis under glass. Zashchita Rastenii 6:24

SIFA (Servicio de información fitosanitaria de Almería) (2004) Organismos de control biológico

Silva L, Smith CW (2006) A quantitative approach to the study of non-indigenous plants: an example from the Azores archipelago. Biodivers Conserv 15:1661-1679

Simberloff D (1996) Risks of species introduced for biological control. Biol Conserv 78:185-192

Simberloff D (1989) Which insect introductions succeed and which fail? In: Drake JA, Mooney HA, di Castri F, Groves RH, Kruger FJ, Rejmánek M, Williamson M (eds) Biological invasion: a global perspective. Scope 37. Wiley, Chichester

Simberloff D (2004) Community ecology: is it time to move on? Am Nat 163:787-799

Simberloff D, Stiling P (1996) How risky is biological control? Ecology 77:1965-1974

Snyder WE, Clevenger GM (2004) Negative dietary effects of Colorado potato beetle eggs for the larvae of native and introduced ladybird beetles. Biol Control 31:353-361

Snyder WE, Clevenger GM, Eigenbrode SD (2004) Intraguild predation and successful invasion by introduced ladybird beetles. Oecologia 140:559-565

Soares AO, Serpa A (2007) Interference competition between ladybird beetle adults (Coleoptera: Coccinellidae): effects on the growth and reproductive capacity. Popul Ecol 49:37-43

Soares AO, Coderre D, Schanderl H (2001) Influence of phenotype on fitness parameters of Harmonia axyridis Pallas (Coleoptera: Coccinellidae). Eur J Entomol 98:287-293

Soares AO, Coderre D, Schanderl H (2003a) Effect of temperature and intraspecific allometry on predation by two phenotypes of Harmonia axyridis Pallas (Coleoptera: Coccinellidae). Environ Entomol 32:939-944

Soares AO, Elias RB, Resendes R, Figueiredo H (2003b) Contribution to the knowledge of the Coccinellidae (Coleoptera) fauna from the Azores islands. Arquipélago Life Mar Sci 20A:47-53

Soares AO, Coderre D, Schanderl H (2004) Dietary self-selection behaviour by the adults of the aphidophagous ladybeetle Harmonia axyridis (Coleoptera: Coccinellidae). J Anim Ecol 73:478-486

Soares AO, Coderre D, Schanderl H (2005) Influence of prey quality on the fitness of two phenotypes of the adults of Harmonia axyridis. Entomol Exp Appl 114:227-232

Stals R, Prinsloo G (2007) Discovery of an alien invasive, predatory insect in South Africa. The multicoloured Asian ladybird beetle, Harmonia axyridis (Pallas) (Coleoptera: Coccinellidae). S Afr J Sci 103:123-126

Stastny M, Schaffner URS, Elle E (2005) Do vigour of introduced populations and escape from specialist herbivores contribute to invasiveness? J Ecol 93:27-37

Stathas GJ, Eliopoulos PA, Kontodimas DC, Giannopapas J (2001) Parameters of reproductive activity in females of Harmonia axyridis (Coleoptera: Coccinellidae). Eur J Entomol 98:547-549

Staverloekk A, Saethre MG, Haagvar E (2007) A review of the biology of the invasive harlequin ladybird Harmonia axyridis (Pallas, 1773) (Coleoptera, Coccinellidae). Nor J Entomol (in press)

Stewart LA, Dixon AFG (1989) Why big species of ladybird beetles are not melanic? Funct Ecol 3:165-177

Stuart RJ, Michaud JP, Olsen LE, McCoy CW (2002) Lady beetles as potential predators of the root weevil Diaprepes abbreviatus (Coleoptera: Curculionidae) in Florida citrus. Fla Entomol 85:409-416

Tan CC (1946) Mosaic dominance in the inheritance of color patterns in the lady-bird beetle, Harmonia axyridis. Genetics 31:195-210

Tan CC (1949) Seasonal variations of color patterns in Harmonia axyridis. Proceedings of the 8th international congress genetics, pp 669-670

Tedders WL, Schaefer PW (1994) Release and establishment of Harmonia axyridis (Coleoptera, Coccinellidae) in the southeastern United-States. Entomol News 105:228-243

Watanabe M (2002) Cold tolerance and myo-inositol accumulation in overwintering adults of a lady beetle, Harmonia axyridis (Coleoptera: Coccinellidae). Eur J Entomol 99:5-9

Vermeij GJ (1996) An agenda for invasion biology. Biol Conserv 78:3-9

Vermeij GJ (2005) Invasion as expectation-A historical fact of life. In: Sax DF, Stachowicz JJ, Gaines SD (eds) Species invasions-insights into ecology, evolution and biogeography. Sinauer Associates, Inc. Publishers, Massachusetts

Vitousek PM, Di Antonio CM, Loope LL, Westbrooks R (1996) Biological invasions as a global environment change. Am Sci 84:468-487

Vitousek PM, Di Antonio CM, Lloyd L Loope LL, Rejmánek M, Westbrooks R (1997) Introduced species: a significant component of human-caused global change. N Z J Ecol 21:1-16 
Ware RL, Majerus MEN (2007) Intraguild predation of immature stages of British and Japanese coccinellids by the invasive ladybird Harmonia axyridis. BioControl (this issue). doi:10.1007/s10526-007-9135-8

Whittaker RJ, Fernández-Palacios JM (2007) Island biogeography-ecology, evolution and conservation. Oxford University Press, Oxford

Williamson M (1981) Island populations. Oxford University Press, Oxford

Williamson M (1996) Biological invasions. Chapman \& Hall, London

Wise IL, Turnock WJ, Roughley RE (2001) New records of Coccinellid species for the province of Manitoba. Proc Entomol Soc Man 57:5-10

With KA, Pavuk DM, Worchuck JL, Oates RK, Fisher JL (2002) Threshold effects of landscape structure on biological control in agroecosystems. Ecol Appl 12:52-65

Yasuda H, Ohnuma N (1999) Effect of cannibalism and predation on the larval performance of two ladybird beetles. Entomol Exp Appl 93:63-67

Yasuda H, Kikuchi T, Kindlmann P, Sato S (2001) Relationships between attack and escape rates, cannibalism, and intraguild predation in larvae of two predatory ladybirds. J Insect Behav 14:373-384 